and VLDL, LDL and HDL cholesterol as risk factors in the development of coronary artery dissease in male patients examined by angiography. Atherosclerosis 1981 ; 39: 411-24.

2 Sniderman A, Shapiro S, Marpole D, Skinner B, Teng B, Kwiterovich PO. Association of coronary atherosclerosis with hyperapobetalipoproteinemia [increased protein but normal cholesterol levels in human plasma low density ( $\beta$ ) lipoproteins]. Proc Natl Acad Sci USA 1980; 77: 604-8.
3 De Graeve J, Bouissou H, Thiers JC, Fouet J, Valdiguie $\mathbf{P}$. Is cutaneous apoprotein $\mathbf{B}$ a better discriminator than serum lipoproteins for atherosclerosis? Atherosclerosis 1984; 52: 301-7.

4 Milne RW, Douste-Blazy P, Marcel YL, Retegui L. Characterization of monoclonal antibodies against human apolipoprotein E. F Clin Invest 1981; 68: 111-7.

5 Wulfert E, Legendre C, Thiers JC, De Graeve J, Solera ML, Bouissou H. Determination of apoprotein B in the skin. Pathol Biol (Paris) 1984; 32: 70-2.

\title{
Coronary artery bypass grafting and hyperlipidaemia
}

Sir,

In a recent editorial (1985; 53: 237-9) Thompson and Sapsford advocate energetic long term treatment of hyperlipidaemia to avert graft failure after coronary bypass surgery. This recommendation is based on recent reports that attempted to link progression of atherosclerosis in the native circulation and in venous bypass grafts to serum lipids. ${ }^{1}$ Other studies from the same institution ${ }^{23}$ and from a different one, ${ }^{4}$ however, found no correlation between serum lipids and progression of coronary atherosclerosis.

In a long term follow up of a series of patients with both internal mammary artery and vein grafts we found graft atherosclerosis exclusively in vein grafts; internal mammary artery grafts in the same patients were spared. ${ }^{5}$ It is clear, therefore, that factors other than lipids play a more important role in graft atherosclerosis. Venous autografts are destined to fail in the long run irrespective of serum lipid concentrations. The treatment of hyperlipidaemia, therefore, is unlikely to have a significant impact on graft survival. The answer probably lies in choosing biologically superior material, such as internal mammary artery grafts.

\section{Ram N Singh, * \\ Julio A Sosa, $\dagger$ \\ *Montefiore Hospital, \\ Pittsburgh, \\ Pennsylvania 15213, \\ USA;}

†Albany Medical Center,

Albany,

New York,

USA.

\section{References}

1 Campeau L, Enjalbert M, Lespérance J, et al. The relation of risk factors to the development of atherosclerosis in saphenous-vein bypass grafts and the progression of disease in the native circulation. A study 10 years after aortocoronary bypass surgery. $N$ Engl $\mathcal{F}$
Med 1984; 311: 1329-32.

2 Moise A, Théroux P, Taeymans Y, et al. Clinical and angiographic factors associated with progression of coronary artery disease. $\mathcal{F}$ Am Coll Cardiol 1984; 3: 659-67.

3 Moise A, Bourassa MG, Théroux P, et al. Prognostic significance of progression of coronary artery disease. Am $\mathcal{F}$ Cardiol 1985; 55: 941-6.

4 Kramer JR, Matsuda Y, Mulligan JC, Aronow M, Proudfit WL. Progression of coronary atherosclerosis. Circulation 1981; 63: 519-26.

5 Singh RN, Sosa JA, Green GE. Internal mammary artery versus saphenous vein graft. Comparative performance in patients with combined revascularisation. Br Heart $\mathcal{F}$ 1983; 50: 48-58.

This letter was shown to the authors, who reply as follows:

Sir,

The contention of Singh and Sosa that internal mammary artery grafts develop less in the way of late atheromatous changes than do saphenous vein grafts has no bearing on whether the latter survive longer in normolipidaemic than in hyperlipidaemic subjects. This is a separate issue. Whether or not internal mammary artery grafts last longer may be relevant to patients who will need coronary artery bypasses in the future but not to the many thousands who already have saphenous vein grafts. We believe that the study of Campeau et al ${ }^{1}$ showed a definite correlation between hyperlipidaemia and late vein graft closure and we consider that this justifies lipid lowering treatment, although we acknowledge that this advice is based on data showing nonprogression of disease in native vessels ${ }^{23}$ rather than in vein grafts.

G R Thompson,

R Sapsford,

Medical Research Council Lipoprotein Team, and

Department of Surgery, Royal Postgraduate Medical School,

Hammersmith Hospital,

Ducane Road, London W12 0HS. 


\section{References}

1 Campeau L, Enjalbert M, Lespérance J, et al. The relation of risk factors to the development of atherosclerosis in saphenous-vein bypass grafts and the progression of disease in the native circulation. A study 10 years after aortocoronary bypass surgery. $N$ Engl $\mathcal{F}$ Med 1984; 311: 1329-32.
2 Brensike JF, Levy RI, Kelsey SF, et al. Effects of therapy with cholestyramine on progression of coronary arteriosclerosis: results of the NHLBI type II coronary intervention study. Circulation 1984; 69: 313-24.

3 Nikkilá EA, Viikinkoski P, Valle M, Frick MH. Prevention of progression of coronary atherosclerosis by treatment of hyperlipidaemia: a seven year prospective angiographic study. $\mathrm{Br} \mathrm{Med} \mathcal{F}$ 1984; 289: 220-3.

\section{Notices}

\section{Stress, behaviour and coronary disease}

An international congress on stress, behaviour and coronary disease will be held in Melbourne from 16 to 21 February 1986. Further details may be obtained from the Mental Health Foundation of Australia, Suite 23, 20 Commercial Road, Melbourne, Australia 3004.

\section{Electrocardiology}

The XIIIth International Congress on Electrocardiology will be held in Washington DC from 10 to 12 September 1986 . For details write to $\mathrm{Dr}$ P W Macfarlane, University Department of Medical Cardiology, Royal Infirmary, Glasgow G31 2ER, Scotland.

\section{British Cardiac Society}

The Autumn Meeting will be held at the Wembley Conference Centre, London, on 26 to 28 November 1985 , and the closing date for receipt of abstracts was 1 August 1985.

The Annual General Meeting for 1986 will take place in York on 2 and 3 April 1986, and the closing date for receipt of abstracts will be 2 January 1986. 